\title{
木造住宅用耐震補強技術の費用対効果に関する試算 TEST CALUCULATION ON COST-EFFECTIVENESS OF SEISMIC RETROFIT MEASUREMENT FOR VULNERABLE WOOD HOUSES
}

\author{
佐 藤基志*, 五十田 博**, 佐藤友彦***, 三宅辰 哉**** \\ Motoshi SATO, Hiroshi ISODA, Tomohiko SATO \\ and Tatsuya MIYAKE
}

\begin{abstract}
This paper describes a case study of cost-effectiveness of seismic retrofit measurement for vulnerable wood houses. To examine the cost -effectiveness of seismic retrofit measurement, the life cycle costs for five houses having different seismic performance and being located on five different areas are compared. These seismic performances are defined from the results of full-scale shaking table tests including collapse tests and static loading test on the site, and time history analyses were conducted to compute damage cost. The field survey also was conducted to evaluate the relationship between damage and rehabilitation. As the result of analyses, there are quite big differences in seismic zone. For example in Shizuoka where is high probability of severe earthquake seismic performance assessment score of 1.5 is the most cost-effectiveness, but then in Tokyo seismic performance assessment score of 0.3 which means no reinforcement of vulnerable wood house is the most cost effectiveness in next 20 year. When calculating the effective cost in next 20 year all area, it is estimated half of the current amount.
\end{abstract}

Keywords: Existing wood house, Seismic diagnosis, Seismic retrofit, Full-scale shaking table test, cost-effectiveness 既存木造住宅、耐震診断、耐震補強、実大振動台実験、費用対効果

\section{1.はじめに}

1981 年の耐震規定、いわゆる新耐震設計基準以前に建てられた木 造住宅には、耐震性能が不十分と推定されるものが数多く存在し、 大地震を受けた際に重大な被害を受ける可能性が指摘されている。 このような現行法の耐震基準に適合しない既存不適格木造住宅は 1000 万棟に達するとも言われている。2004 年新潟県中越地震や 2007 年能登半島地震を経験し、東海、東南海をはじめとする大地震の発 生が危惧されている昨今、個々の住宅レベルにおいては耐震補強を 推進し、都市計画レベルにおいては被害状況の予測をするなど、総 合的な地震防災対策を構築することが社会的急務である。しかし、 現状は地震災害に関する理解が浸透しておらず、耐震化が思うよう に進んでいない。その理由として、一般住民が抱く耐震診断・補強 に対する信用度の低さや、目では確認することの出来ない補強効果、 費用対効果に対する不安、そしてなによりも個人の災害意識の低さ があげられる。

本論文では木造住宅の耐震補強の費用対効果について論じる。費 用対効果は、経済原理に則りその長期的な有効性を明らかにするも のである。本来、木造住宅の耐震補強は人命にかかわる事象であり、 金額に置き換えることができない事象について、いたずらに経済原 理を持ち出し、有効性を論じることは慎むべきである。しかし、本 論文では、進まない耐震補強の一助となる工学的な観点からの基礎 資料を得ることや、耐震補強にあっては経済的な観点からも有益な 結果が得られるような技術開発の促進に寄与寸ること目指し、費用
対効果の試算をおこなった。

本論文で参考にした既往の研究は、建物の供用期間を通しての地 震被害と復旧に関する出費(以下、地震リスクに対する損失額)をり スクととらえ、複数の設計案の中から、地震リスクに対する損失額 が最小となる設計案の提案が可能となるリスク・マネジメント手法 である ${ }^{1,2)}$ 。本研究では 3 章で詳述する図 1 に示すような手順に沿っ て費用対効果を計算した。まず、評点別の建物モデルの作成をおこ なう。既往の研究では、構造設計の元となる壁の荷重変形関係など を参考に建物モデルを定義し、過去の地震被害との関係によってモ

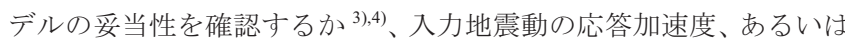
応答速度と建物の被害との関係から被害関数曲線など定義する手法 5,6)など、が用いられることが多いが、ここではこれまで実施した実 大実験の結果に基づいて、評点に応じた振動モデルの作成を試みた。 ついで、入力地震動を定義する。特定の地域の地震動を論じる場合、 周辺の断層を考慮し理論的地震動評価として統計的グリーン関数に より時刻歴地震動を得る方法 7),8 などが現段階では適切と考えられる が、本論文では多地点での地震動を容易に得るため、経験的地震動 評価として回帰分析に基づく応答スペクトルから得られる模擬地震 動に対して、日本建築学会「建築物荷重指針・同解説 2004 （以下、 荷重指針)」9)に示されている八ザードマップを適用し、加速度と再 現期間の関係を定義した。そして、損傷費用と耐震補強コストを算 出する。損傷費用については既往の研究 ${ }^{2}$ )で用いられている損傷費 用曲線を参考とするとともに、損傷程度と建て替え割合に関する基

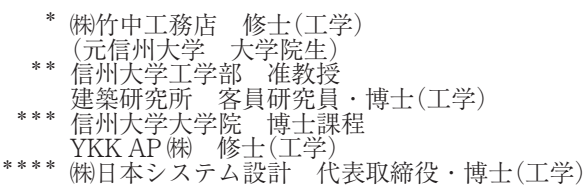

Takenaka Corp., M. Eng.

Assoc. Prof., Shinshu University

Visiting Researcher, BRI, Dr. Eng.

Graduate Student, Shinshu University

YKK AP, M. Eng.

President, Nihon System Sekkei Architect \& Engineers Co., Ltd., Dr. Eng. 
礎資料が尔足していたので、2004 年新潟県中越地震の復壮状沙の調 查によってそれを明らかにした。耐震補強費用はこれホで捉案され

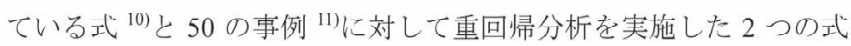
で比洨検討している。最後に地震リスクに対する損失額老求め、現 在の耐震補強費用での) 今後(供用期間と目標評点との関係を示した さらに、評点 1.0 や 1.5 を目標として費用対効果が得られう而震補 強コหトについて一考した。

\section{2. リスク・マネジメント手法}

まず、本論文で用いたリスク・マネジメント手法について簡単に

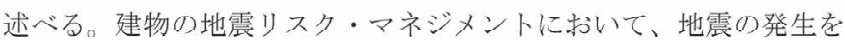
更新過程 の一ーであるポソンン過程とした場合、西る設計案 $の$ 期待 地震リ火》に詨寸る損失額は、式(1)の)ように定式化される2。

$$
E\left[C_{L}\right]-C_{I}+t_{\text {lffo }} \times \sum_{\text {all-sulurep }} \sum_{j=1}^{k} v\left(m_{j}\right) \cdot E\left[C_{D}\left(m_{j}\right)\right]
$$

ここで $\mathrm{E}[\cdot]$ は確悴変数・( 期待佔、 $C_{r}$ は地震リス夕に対する損 失額、 $C_{l}$ は初期費用、 $C_{D}\left(m_{j}\right)$ は最大加速度 $\left.m_{j} 0\right)$ 地震に対寸る損倁費

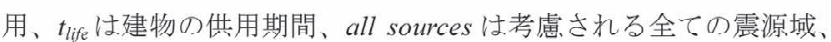

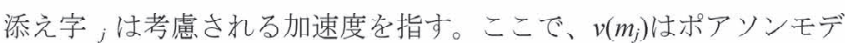
儿在仮定した際( 、最大加速度 $m_{j}($ ()地震 (て)単位時閒当たり(て)発生率 である。

\section{3. 耐震補強の費用対効果の評価方法}

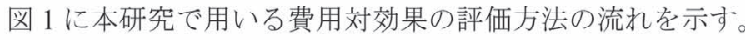

ホず、モデル化(て)作成に执いて

(1) 過去に実施した実大振動台実験(て)絬果に基づき、耐震診断評点 $0.3 、 0.5 、 0.7 、 1.0 、 1.5$ (建物モデルを作成する。

(2) 対象上なる位宅の価格の初期費用の算出走昖:なら。同じく対

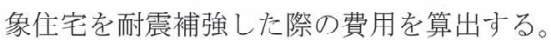

次いで、入力地震波に抒いた。

(3) 解放的工学基盤に対して10 波( 模擬波表作成し、5つ( T)地盤表 考慮して合計 50 波( 模擬地震動老作成する。基盤( 最大加速 度䘮パラメータとし、ハザードマッブより最大加速度でレの年 発生率学定好る。

そして、損傷費用の算出に括いて、

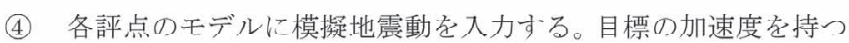
地震動 50 波に対する最大応答変形至得る。別途作成した最大 応答変形上損傷費刀の関係より、各訂点の入力最人加速度に対 一る損傷費用の算出索蛼る。

最後に、地震リスクに対可る損失額の算出に执いて

(5)己れぞれのパラメータ先地震りス》に対可る愪火額の定式(1) に代入することで診断評点ごよ( 地震り久》に対する損火額る 求ぬる。

（6）耐震診断評点べとの地震りスクに対する損失額の比較を㧍いな

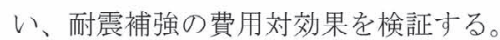

それ、ぞれの)項月の)詳紐は 4 章以降(゙述べる。

4. モデルの作成

4.1 荷重変形関係の基準化 前述したよりに刘象の建物山、耐震䛦断

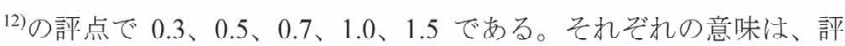

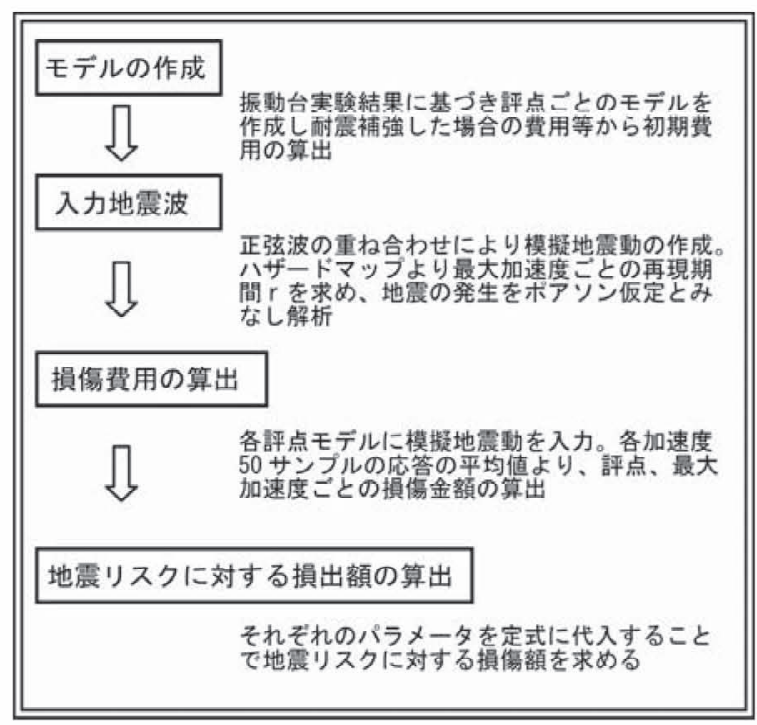

图 1 費刃対效果の謤価方法

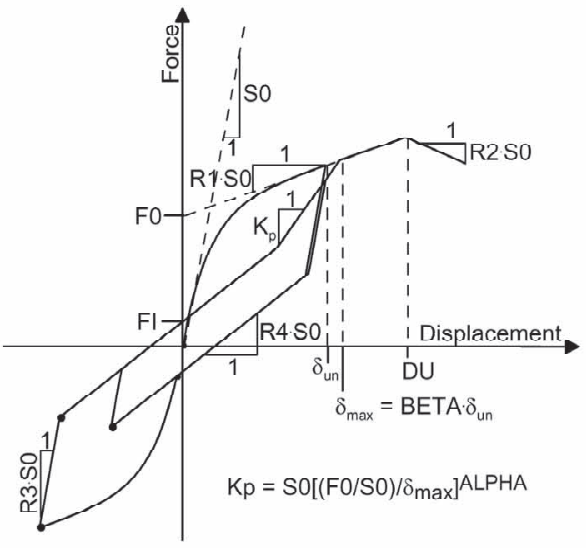

骨格曲線は下式による $F=\left(\begin{array}{ccc}\operatorname{sgn}(\delta) \cdot(F 0+R 1 \cdot S 0|\delta| \cdot\{1-\exp (-S 0|\delta| / F 0\} & |\delta| \leq|D U| \\ \operatorname{sgn}(\delta) \cdot F U+R 2 \cdot S 0 \cdot\{\delta-\operatorname{sgn}(\delta) \cdot D U\} & |D U|<|\delta| \leq|D F| \\ 0 & |\delta|>|D F| & \end{array}\right)$

$D F ：$ 負勾配が $\mathrm{X}$ 軸と交わる点

図 2 復元力特吽モデル

点 $0.7 、 1.0 、 1.5$ が耐震診断において、「倒壞する可能性がある」、「一 応倒壞しない」、「倒壊しない」の境界であり、0.3、0.5 は耐震補強

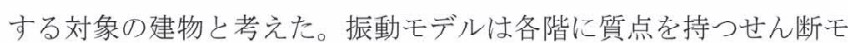

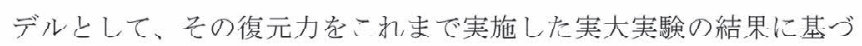
き定妨る復元ノ特性は図 2 に示文、CUREE-Caltech Wood frame Project ${ }^{(3)}$ に标いて、Bryan ${ }^{14)}$ により提案されたチデルとした。

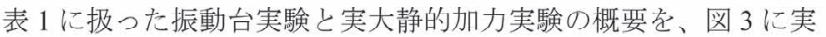
大実騒ゆ絬果及び、実験絬果から基淮化した デル」)の荷重变形関係を示す。実験絬果の綐軸以層子久断力主全重 量上評点で除 L, て基準化 L、横俥法層間变形角上Lて示 L后結果で

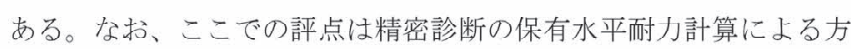
江により求好值て，その際の層の荷重変形関倸は、壁単体の荷重 変形関倸の匡叔好せ上して求为ている。壁単体の荷車変形関倸は 実験絃果がある埙合にはその值在用い、ない翢合には文献 11)の参

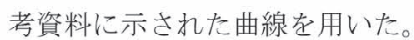

結果は大きくばらのいているが、大局的に一のに分類可能である。 
表 1 荷重変形関係の定義に用いた実験の概要

\begin{tabular}{|c|c|c|c|c|c|c|c|c|c|}
\hline & 仕上げ & 耐震要素 & 面積 $\left(\mathrm{m}^{2}\right)^{* 1}$ & 重量 $(\mathrm{kN})$ & 評点 & 入力地震動 (入力回数) & 入力方向 & 最大変形角 & 文献 \\
\hline 既存 A & モルタル & 筋かい & 47.80 & 185.2 & 0.78 & JMA 神戸波 (3) & $\mathrm{XZ}$ & $\begin{array}{c}\text { 倒壊 } \\
\end{array}$ & 15) \\
\hline 既存 B & モルタル & 筋かい & 42.78 & 210.5 & 0.50 & JR 鷹取波 & $\mathrm{XYZ}$ & 倒壊 & 16) \\
\hline 既存 C & 下見板 ${ }^{* 2}$ & 筋かい & 48.86 & 239.7 & 0.52 & 引き倒し実験 & $\mathrm{X}$ & 倒壊 & 17) \\
\hline 既存十補強 & モルタル & 筋かい、構造用合板 & 42.78 & 210.5 & 1.84 & JR 鷹取波 (2) & $\mathrm{XYZ}$ & 倒壊 & 17) \\
\hline 新築 $\mathrm{A}$ & サイディング & 筋かい、構造用合板 & 76.60 & 267.7 & 2.06 & JMA 神戸 JR 鷹取 (3) & $\mathrm{XYZ}$ & 倒壊 & 18) \\
\hline 新築 $\mathrm{B}$ & なし & 筋かい、構造用合板 & 52.99 & 173.4 & 1.48 & JMA 神戸 & XYZ & $1 / 5 \mathrm{rad}$ & 19) \\
\hline 新築 $\mathrm{C}$ & なし & 筋かい、構造用合板 & 52.99 & 173.4 & 1.84 & JMA 神戸 & $\mathrm{XYZ}$ & $1 / 17 \mathrm{rad}$ & 19) \\
\hline
\end{tabular}

*1 面積は 1 階の床面積を示す。

*2 下見板は耐震診断 ${ }^{11}$ に示された曲線を用いて荷重変形関係を求めた。

ひとつは新築建物を対象にした実験結果や補強建物の実験結果で、 変形性能は異なるものの縦軸の荷重は比較的安定している。もうひ とつは、既存建物を対象にした実験結果で、新築建物や補強建物よ り全体的に耐力が大きい。新築建物は、接合部や配置の低減などな く、壁の実験の重㸚あわせで精度よく荷重変形が求められる。一方、 既存建物の診断は接合などの不確定な要素が多く、安全側に評価さ れているといえる。この安全側の評価は、既存壁の荷重変形関係の データベースが希少であること、さらに、柱一横架材接合部や劣化 の低減方法の問題、さらにモルタル外壁のような仕上げ材に対して 単純な重社合わせが成り立つか、などに起因すると考えられる。今 後、耐震診断技術の高度化、精緻化が図られ、前述のような問題点 が解決された場合には、既存建物も新築建物と同様に評価值と荷重 変形関係の対応の精度が高まると考えられるので、基準化モデルの 復元力特性の骨格曲線は、新築建物の平均的な值として定めた。繰 り返しのパラメータは壁実験の結果 ${ }^{20)}$ などを参考に表 2 に示すとお りに定めた。図 4 には定めた骨格曲線の一例として、既存建物と補 強建物の荷重変形関係とモデルのそれを比較して示した。既存建物 では差が大きいものの、補強建物では良好な一致となっている。

4.2 評点モデルの作成 まず、「基準化モデル」に基づいて、2 階建 て建物の 2 質点系せん断モデルのうち、1 階の荷重変形を定義した。 つまり、1 階の各評点モデルの荷重変形関係は、図 3 の縦軸の值に 評点と重量を掛け合わせることにより荷重を、変形角に階高を乗じ ることで変形とした。2 階の荷重変形関係は「評点 0.3 モデル」、「評 点 0.5 モデル」、評点 0.7 モデル」においては 1 階に対して 1.5 倍と し、「評点 1.0 モデル」の 2 階評点は「評点 0.7 モデル」と合わせ評 点 1.05 に、そして「評点 1.5 モデル」は $1 、 2$ 階とも同じ評点とし

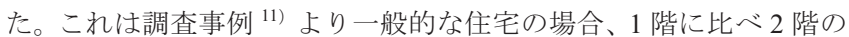
評点が高い例が多く、その倍率がおおよそ 1.5 倍程度と判断したこ と、耐震補強の際は $1 、 2$ 階とも同程度に補強寸ると考えられること、 による。なお、2 質点系せん断モデルの重量及び階高は、実大実験 の試験体「既存十補強」に合わせ、それぞれ 1 層 $210 \mathrm{kN} 、 2,850 \mathrm{~mm}$ 、

2 層 $91.4 \mathrm{kN} 、 2,700 \mathrm{~m}$ として、せん断バネを求めた。

4.3 建物費用の設定 対象地域は東京、大阪、名古屋、長野、静岡 の 5 地域とした。建築物価調査会の建築着工データファイル平成 18 年度計 ${ }^{21)}$ よりそれぞれの地域での木造建物の調查対象棟数、延床面 積の平均、工事費単価を求め、面積と建築費単価を乗じて対象建物 モデルの地域ごとの価格を定めた。表 3 に地域ごとの建築費単価、 延床面積、モデル価格を示す。家財の価格は文献 2 ) と同様に 1 人当 たり 300 万円として計算し、本解析では 4 人家族、1200 万円とした。

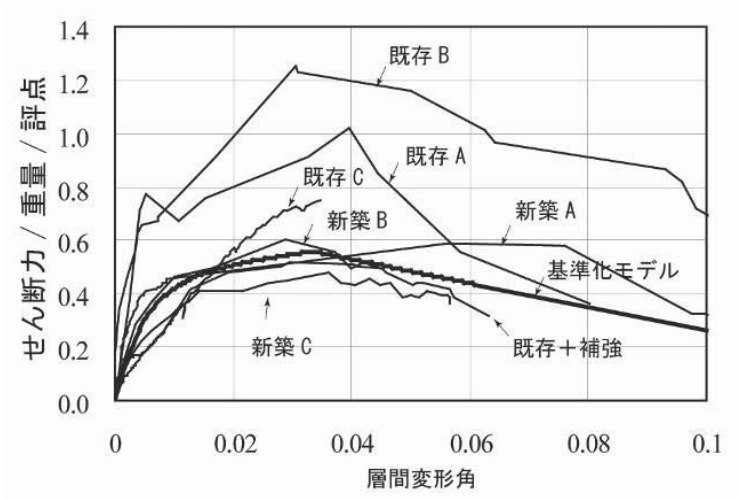

図 3 荷重変形関係比較

表 2 繰り返しパラメータ

\begin{tabular}{c|c|c|c}
$F 0$ & 骨格曲線による & $R 2$ & 骨格曲線による \\
\hline$F I$ & $F(D U) \times 0.114$ & $R 3$ & 1.00 \\
\hline$D U$ & 骨格曲線による & $R 4$ & 0.19 \\
\hline$S 0$ & 骨格曲線による & $A L P H A$ & 0.55 \\
\hline$R I$ & 骨格曲線による & $B E T A$ & 1.26
\end{tabular}
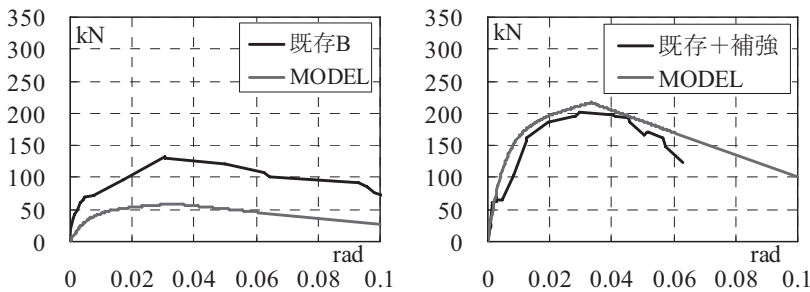

図 4 モデルと実験結果の比較

表 3 地域ごとの建物モデル価格

\begin{tabular}{c|c|c|c|c} 
& 棟数 & 面積平均 & 工事費 $/ \mathrm{m}^{2}$ & モデル価格 \\
\hline 単位 & 棟 & $\mathrm{m}^{2}$ & 万円 & (万円) \\
\hline 東京 & 35735 & 111.5 & 17.6 & 1961.2 \\
\hline 大阪 & 24889 & 111.7 & 16.1 & 1796.8 \\
\hline 名古屋 & 5641 & 127.2 & 16.3 & 2070.3 \\
\hline 長野 & 10232 & 128.8 & 16.2 & 2089.9 \\
\hline 静岡 & $\begin{array}{c}16449 \\
\text { 注 面積平均 : 述床面積の平均、工事費 : 工事費単価 }\end{array}$
\end{tabular}

4.4 耐震補強費用 耐震補強費用は、耐震補強の事例 50 例 $\left.{ }^{11}\right)$ の重回 帰分析から定牥法（以後「重回帰算定式」）と、狩谷らにより報 告 ${ }^{10)}$ されている補強費用の算定式(以後「既往式」)の 2 ついいて 検討した。狩谷により報告されている式は日本木造住宅耐震補強事 
業者協同組合に加盟している企業から提供された 145 件の耐震補強 工事データに基づくものである。なお、ここでの耐震診断は改定さ れる以前のもの 22)を用いている。改定後の診断法では柱横架材接合 部の低減などがかかるため、診断評点は一般に小さな值となると考 えられるが、ここでは別調查による参考值として評点をそのままに 式を引用した。

まず、重回帰算定式による耐震補強費用は、説明変数として「評 点上昇度」、「補強前評点」を決めた。両変数は相関があると考えら れるが、これまでの研究において「評点上昇度」はもとより、「補強 前評点」によっても補強費用に明確な違いが見られたという理由に より変数とした。次いで「延べ床面積」を取り上げ、「評点上昇度」、

「補強前評点」との相関が 0.10 と低いことを確認した上で、「延べ 床面積」を変数に加えた。以上、 3 つの説明変数に対して「耐震補 強費用」の重回帰式(2)を求めた。

$\mathrm{C}_{1}=1.22 \mathrm{x}+77.9 \mathrm{y}+458 \mathrm{z}-149$

ここで

$\begin{array}{ll}\mathrm{C}_{1} \text { : 耐震補強費用 }(\text { 万円) } & \mathrm{x} \text { : 延心゙床面積 }\left(\mathrm{m}^{2}\right) \\ \mathrm{y}: \text { 補強前評点 } & \mathrm{z} \text { : 評点上昇值 }\end{array}$

既往式では、耐震補強費用は「評点上昇度」「補強前評点」によ って式(3)(4)(5)で表される。

$\mathrm{Ei}=\mathrm{Ea}-\mathrm{Eb}$

$\mathrm{Ei}=0.85^{*} \operatorname{In}\left(\mathrm{C}_{2}\right)-11.69 \quad(\mathrm{~Eb}<0.7 \quad$ 相関係数 0.984$)$

$\mathrm{Ei}=1.45 * \operatorname{In}\left(\mathrm{C}_{2}\right)-19.48 \quad(0.7 \leqq \mathrm{~Eb}<1.0 \quad$ 相関係数 0.762$)$ ここで
$\mathrm{Ei}$ : 評点上昇度
Ea : 補強後評点
$\mathrm{Eb}$ : 補強前評点
$\mathrm{C}_{2}$ ：耐震補強費用(円)

図 5 に推定值と実事例による補強費用の分布を示す。事例と重回 帰算定式の相関は 0.487、事例と既往式の相関は 0.387 となった。ま た、重回帰算定式における標準偏差は 91 万円であった。

以上、耐震補強費用について事例と既往式によって定義したが、 補強費用はケースバイケースでバラツキが大きい結果となった。本 研究では耐震補強の平均的な額の例として二つの手法を用いて以後 の論を進める。

\section{5. 入力地震波}

5.1 基盤地震動の作成 ${ }^{23)}$ 解放的工学基盤面の模擬地震動の加速 度時刻歷 $a_{B}(t)$ は、(6)に示寸正弦波の重社合せによって作成する。 $T i$

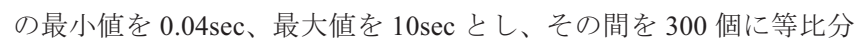
割とした。位相角 $\phi i$ は $0 \sim 2 \pi$ 間の一様乱数とした。加速度 $a(t)$ の時 刻歴波形の包絡線は図 6 のように設定した。本包絡線は文献 ${ }^{23)}$ に示 される包絡関数をもとに、継続時間を 30 秒として独自に設定したも のである。

$$
a_{B}(t)=a(t) \cdot \sum A_{i} \cdot \sin \left(\frac{2 \pi}{T_{i}} \cdot t+\phi_{i}\right)
$$

$a(t)$ : 非定常性を与える包絡関数

$A_{i}: i$ 成分の振幅

$T_{i}: i$ 成分の周期

$\phi \mathrm{i}: i$ 成分の位相角

$A_{i}$ は目標とする加速度応答スペクトルに適合することを条件と
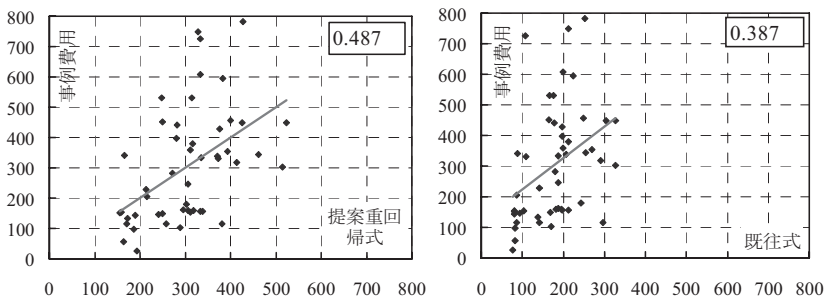

図 5 補強費用の分布 (単位: 万円)

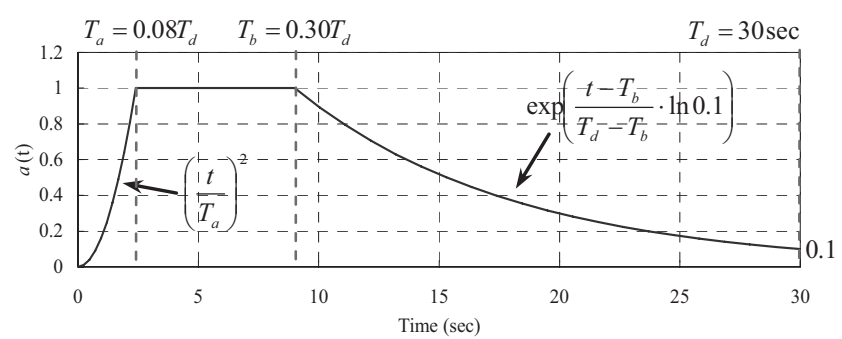

図 6 加速度時刻歴の包絡線

として、収束計算により設定する。収束計算 $j$ ステップにおける $A_{i}$ を $A_{i, j}$ とする。 $A_{i, j}$ は $j-1$ ステップにおける $A_{i}$ をもとに次のように 算定する。

$$
A_{i}=A_{i, j-1} \cdot \frac{S_{a T}\left(T_{i}\right)}{S_{a, j-1}\left(T_{i}\right)}
$$

$$
S_{a T}\left(T_{i}\right): \text { 目標加速度応答スペクトル }
$$

$S_{a . j-1}\left(T_{i}\right): j-1$ ステップにおける $a_{B}(t)$ による加速度応答スペ クトル

収束の判定条件は次の3項目とする。

$$
\begin{aligned}
& \text { 最小スペクトル比 } \varepsilon_{\min }=\min \left(\varepsilon_{i}\right) \geq 0.85 \\
& \text { 目標に対する標準偏差 } \sigma \leq 0.05 \\
& \text { 目標に対する誤差の平均 }|1-\bar{\varepsilon}| \leq 0.02 \\
& \text { ここで、 } \varepsilon_{i}=\frac{S_{a . j}\left(T_{i}\right)}{S_{a T}\left(T_{i}\right)} \quad \sigma=\sqrt{\frac{\sum\left(\varepsilon_{i}-1\right)^{2}}{N}} \quad \bar{\varepsilon}=\frac{\sum \varepsilon_{i}}{N} \\
& N: T_{i} \text { の数 }
\end{aligned}
$$

この方法では $\phi i$ を一様乱数とするため、いくつでも $a_{B}(t)$ を作成 できるが、ここでは 20 波作成し、目標のスペクトルに対してバラッ キが少ない順に 10 波を選択した。

5.2 目標応答スペクトルと再現期間 荷重指針に準拠して基盤地 震動の目標加速度応答スペクトルに対する再現期間を求める。

$A_{\max }$ は荷重指針では次のように与えられる。

$$
A_{\max }=k_{r E} \cdot a_{0}
$$

ここで、再現期間換算係数 $k_{r E}$ は、再現期間 $r$ 年に応じて次のよう に定められる。

$$
k_{r E}=\left(\frac{r}{100}\right)^{1 / k} \quad k=\frac{\ln 500-\ln 100}{\ln a_{500}-\ln a_{0}} \quad r=100 \cdot\left(\frac{A_{\max }}{a_{0}}\right)^{k}
$$

$\mathrm{a}_{0}, \mathrm{a}_{500}$ ：再現期間 100,500 年に対する最大加速度 
表 4 に地震ハザードマップから読み取った、各地域の $\mathrm{a}_{0} 、 \mathrm{a}_{500}$ 、 の值を示す。年発生率は再現期間 $r$ の逆数より求めた。

5.3 表層地盤による地震動の増幅 表層地盤を振動モデルに置換 し、基盤地震動を入力として逐次積分法による応答解析を行って地 表面地震動を求めた。表層地盤の非線形性を表す復元力モデルは今 津・福武による R-O モデル ${ }^{24) 、 25)}$ とした。表層地盤の地層構成は $k-n e t^{26)}$ な゙の公開データから 2 種地盤、3 種地盤に相当するもの 5 つを選定した。式(9)による各表層地盤の略算固有周期を表 5 に示す。

$$
T_{g}=\frac{4\left(\sum D_{i}\right)^{2}}{\sum V_{s i} \cdot D_{i}}
$$

\section{$D i:$ 表層地盤各地層の厚さ}

$V s i:$ 表層地盤各地層のせん断波速度

入力とする基盤地震動の最大加速度を200、300、400、600、800、 $1000 \mathrm{gal}$ の 6 段階に設定して応答解析を行い、それぞれの地盤に対す る地表面地震動を求めた。図 7 に各種地盤での最大加速度 $800 \mathrm{gal}$ で の加速度応答スペクトルを示す。

\section{6. 損傷費用}

6.1 層間変形と損傷費用 作成した模擬地震動を建物モデルに入力

し、得られた最大層間変形より損傷費用を求める。本解析では住宅 の補修費用、あるいは建て替え費用と家財の損傷費用の合計を割合 で求め、最終的には建物の初期費用にそれを乗じることにより $\mathrm{C}_{\mathrm{D}}(m j)$ を求めた。なお、損傷費用の元となる被災建物の費用や建て 替え費用は、4.3 で述べた建物費用と同じと考えた。ここでは被災建 物が経年によって価值が減少していることや補修の際に価值の異な るものが用いられることは考慮していない。

表 6 に建物の層間変形角と損傷状況、ならびに損傷の割合を示し た。まず、区切りとなる層間変形角は、軽微(層間変形角 $1 / 300$ )、小 破(同 1/150)、半壊(同 1/60)、全壊(同 1/30) とし ${ }^{2)}$ 、倒壊限界は過去の 実験結果 $\left.{ }^{16)}, 18\right)$ により復元力がほぼ 0 となる $1 / 6 \mathrm{rad}$ とした。補修費用 も既往の研究 ${ }^{2}$ に準じて定め、層間変形角が大きくなるに従って大 きな割合となり、大破より大きな被害では $100 \%$ つまり初期費用と 同じ額である。建て替えた場合も同様に $100 \%$ である。被害と建て 替えか補修かの復旧状況を判断するための基礎的な資料がないため、 2004 年新潟県中越地震の悉皆調查 ${ }^{27)}$ を実施した建物を対象に現在 の復旧状況を調べ、被害と建て替え、補修の割合を決めた。調查対 象地域は長岡市、川口町及び旧堀之内町で合計 348 棟に対して実施 した。写真 1 に調査対象建物の例を示す。結果は表 6 中下段に示し たとおりであり、外観上無被害と判断された建物であっても少なか らず建て替えているものがあった。最終的には、補修、建て替えに かかる費用の割合を調查で得たそれぞれの割合に乗じて、被害ラン クごとの初期費用に対する損傷費用割合(表 6 中では最下段)を求め た。応答変形とこの損傷費用を関係付ける際は、層間変形角とこの 費用に対しての近似曲線式を求めて、層間変形角を近似式に代入寸 ることで損傷費用の割合を算出した。なお、悉皆調查における被害 の判定には岡田による方法 $\left.{ }^{28}\right)$ が用いられている。悉皆調查時の被災 度とここで定義した損傷状況と層間変形角の関係については、被災 度区分判定基準 ${ }^{29}$ に例示されている各部の被災状況と被災度の関係、

さらに各部の被災状沉と最大層間変形角 $\gamma_{\mathrm{e}}$ の関係から最も近いと 考えられる項目を選択し定めた。家財の損傷費用は、倒壊以前につ いては建物の損傷費用割合の半分を家財の価格に乗じて求め、建物 が倒壊した場合には $100 \%$ の損傷費用がかかるものとして計算した。 図 8 に建物及び家財の層間変形角と損傷費用の関係を示寸。

表 4 再現期間換算係数を決定する特性值

\begin{tabular}{c|c|c|c|c|c} 
& 東京 & 大阪 & 名古屋 & 長野 & 静岡 \\
\hline $\mathrm{a}_{0}$ & 190 & 190 & 210 & 240 & 380 \\
\hline $\mathrm{a}_{500}$ & 340 & 400 & 390 & 450 & 790 \\
\hline $1 / \mathrm{k}$ & 0.361 & 0.462 & 0.384 & 0.390 & 0.455
\end{tabular}

表 5 表層地盤の略算固有周期

\begin{tabular}{c|c|c|c|c|c} 
地盤種別 & 2 種-1 & 2 種-2 & 3 種-1 & 3 種-2 & 3 種-3 \\
\hline $\operatorname{Tg}(\mathrm{sec})$ & 0.345 & 0.696 & 0.812 & 0.923 & 1.197
\end{tabular}
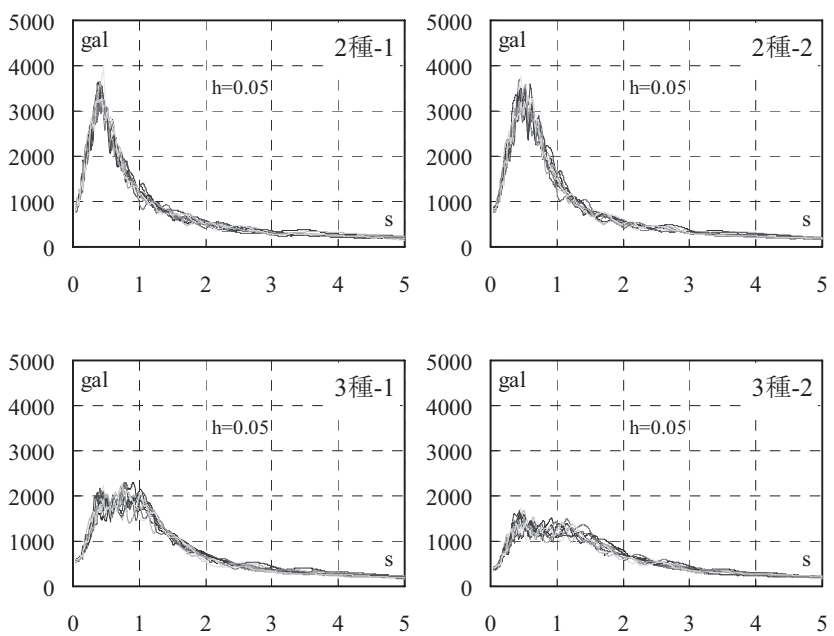

図 7 各地盤の加速度応答スペクトル $800 \mathrm{gal}$

表 6 層間変形と損傷費用

\begin{tabular}{c|c|c|c|c|c|c|c} 
& & \multicolumn{2}{|c|}{ 無被害 } & 一部損傷 & 半壞 & \multicolumn{2}{|c|}{ 全壞 } \\
\hline & & 無被害 & 整微 & 小破 & 中破 & 大破 & 倒壊 \\
\hline & $\mathrm{rad}$ & $\sim 1 / 300$ & $1 / 300 \sim$ & $150 \sim$ & $1 / 30 \sim$ & $1 / 15 \sim$ & $1 / 6 \sim$ \\
\hline 費用 & 補修 & 0 & 2 & 10 & 50 & 100 & 100 \\
\cline { 2 - 8 } 割合 $\%$ & 建替 & 100 & 100 & 100 & 100 & 100 & 100 \\
\hline 復旧 & 補修 & 96.0 & 96.0 & 78.4 & 38.7 & 25.9 & 25.9 \\
\cline { 2 - 8 } 状況 $\%$ & 建替 & 4.0 & 4.0 & 21.6 & 61.3 & 74.1 & 74.1 \\
\hline 費用 & $\%$ & 4.0 & 5.9 & 29.5 & 80.6 & 100.0 & 100.0
\end{tabular}

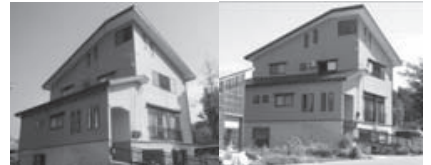

補修例 （全壊）

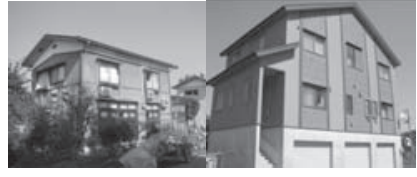

建替え例（全壊）

写真 1 調查対象建物

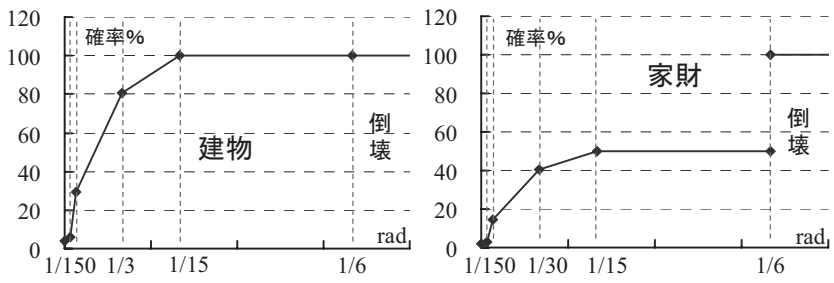

図 8 層間変形とフラジリティ曲線 
6.2 評点ごとの損傷費用算出 作成した建物モデルに対し 200、300、 400、600、800、1000gal の模擬地震動を各加速度 50 波入力し、損傷 費用を算出した。建物と家財の評点、入力加速度ごとの損傷確率変 数を図 9 に示す。

\section{7. 耐震補強の費用対効果の評価}

7.1 地震リスクに対する損失額の算出 図 10、11 に補強前の評点が 0.3 及び 0.5 の建物に対し耐震補強を行なった際の補強後評点別、地 震リスクに対する損失額と供用期間の関係を地域別に示した。地震 リスクに対する損失額は初期のモデル費用を引いた值となっており、 耐震補強を施さない場合の初期の地震リスクに対する損失額 $\left(\mathrm{t}_{\mathrm{life}}=0\right)$ が 0 となるように示してある。なお、地震の発生をポアソン過程と し、耐震補強費用は額が低く算出される狩谷らによる既往式 ${ }^{13)}$ を用
いたものを例としている。図中には現在からの供用期間を 10 年およ び 20 年としたときの耐震補強の最適案及び期待地震リスクに対す る損失額を合わせて示した。また、図 12、13 は最適案がわかりや寸 いように供用年数が 5、10、15、20 年のときの地震リスクに対する
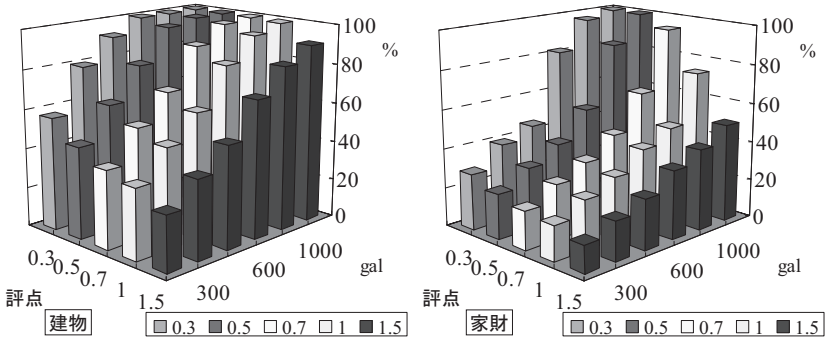

図 9 評点毎の加速度の違いによる損傷確率変数

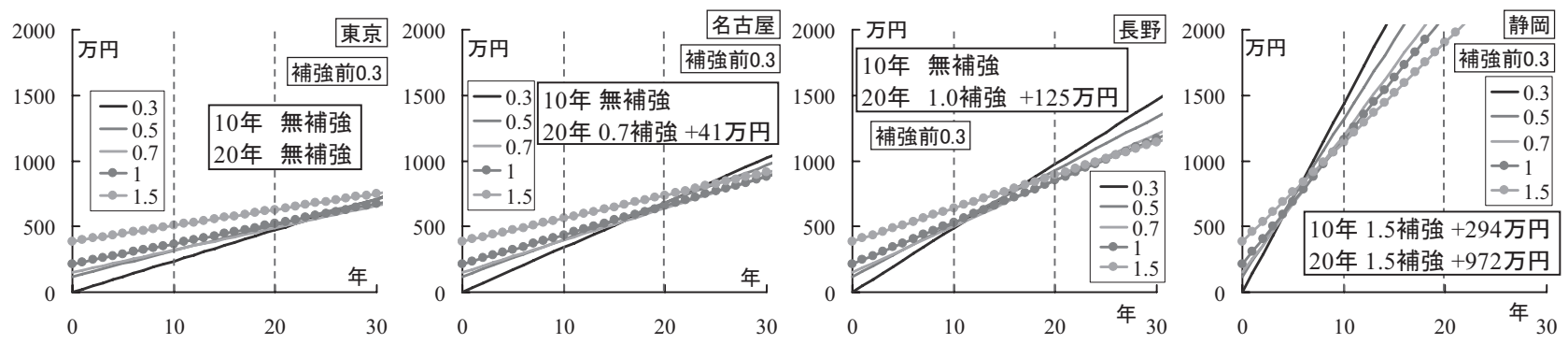

図 10 地域別地震リスクに対する損失額（補強前評点 0.3 )
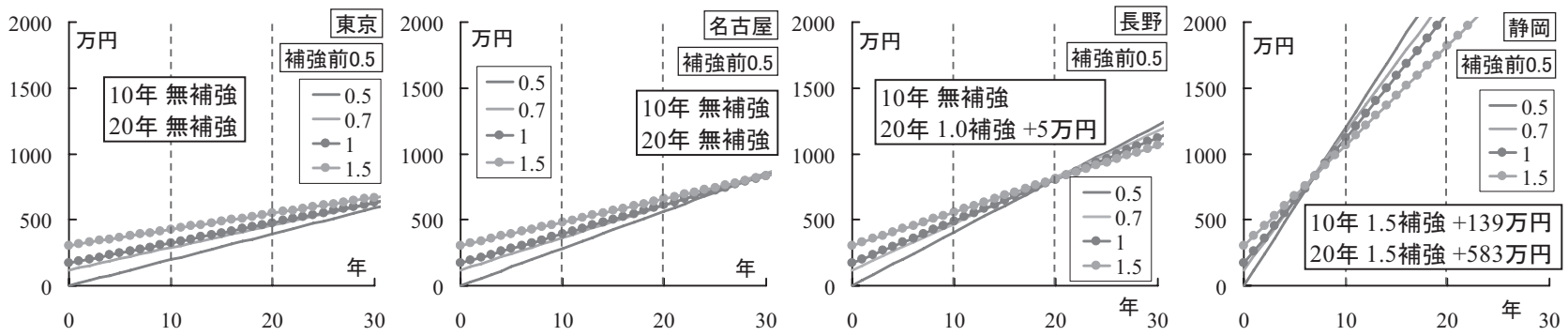

図 11 地域別地震リスクに対する損失額（補強前評点 $0.5 ）$
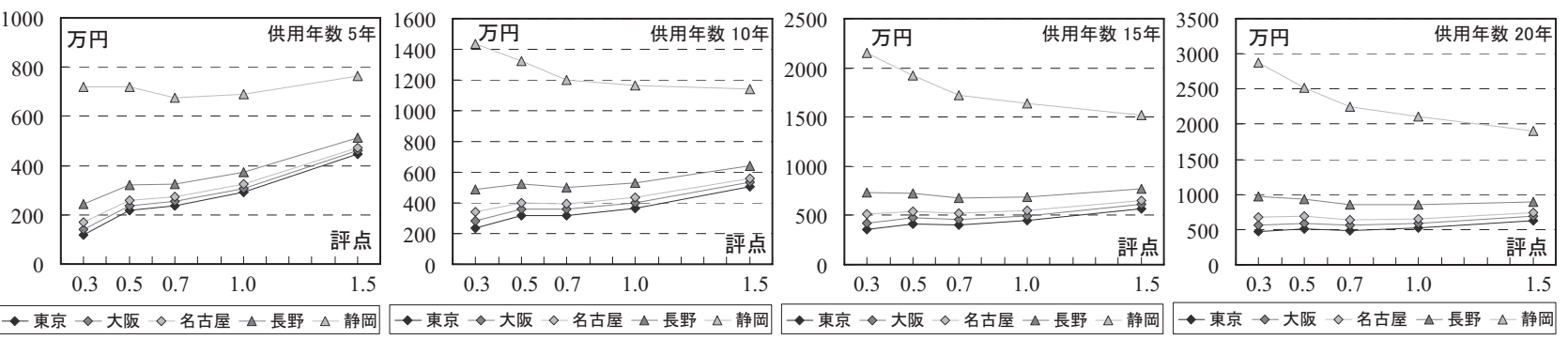

図 12 地域別地震リスクに対する損失額 (補強前評点 0.3 )
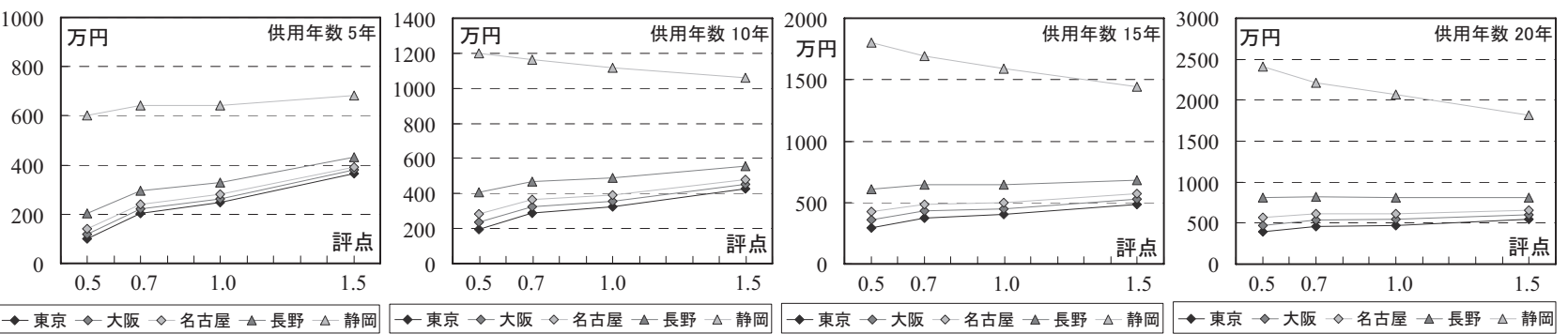

図 13 供用年数別地震リスクに対寸る損失額 (補強前評点 0.5 ) 
損失額を補強後評点ごとに示した。

補強対象建物が評点 $0.3 、 0.5$ のいずれの場合も、地震発生率が 高い静岡を除いて、耐震補強による地震リスクに対する損失額の 軽減は期待できない。つまり、耐震補強しないという選択肢が最 適解となった。一方、静岡は今後の供用期間が 5 年では評点 0.7 までの補強が最適であるが、供用期間 10 年を超えると評点 1.5 ま で補強したほうが高い費用対効果が得られる。例えば、 10 年で 294 万円、 20 年で 972 万円の地震リスクに対する損失額の軽減が期待 される。

7.2 目標評点最適補強費用 7.1 で検討したように地震発生率の 高い静岡を除いて費用対効果が得られないという結果であった。 それでは現在の耐震補強費用がどの程度まで下がれば、効果が現 れるかについて検討する。計算方法は、次のとおりである。

例えば、評点 0.3 モデルと評点 1.5 モデルについて、それぞれ 初期費用を 0 として地震リスクに対する損失額を算出し、ある供 用期間のときの地震リスクに対する損失額の差額 $\mathrm{x}$ を求める。こ こで、評点 0.3 の建物を耐震補強し評点 1.5 まで上げるための費 用がその差額 $\mathrm{x}$ 以下であれば、耐震補強を施したことにより地震 リスクに対する損失額が軽減されたことになるため、その耐震補 強は費用対効果が得られる。このようにして供用期間と目標評点 ごとの「費用対効果の得られる耐震補強費用 $\mathrm{x} 」$ (以下「目標評点 最適補強費用」)を算出した。

図 $14 、 15$ に評点 0.3 、及び 0.5 の建物を評点 1.0 、及び評点 1.5 まで補強した場合の目標評点最適補強費用を供用年数ごとに示し た。現状の耐震補強費用の目安として、既往式及び重回帰算定式 より算出した現状の耐震補強費用もあわせて示した。評点が 0.3 の建物を評点 1.0 まで耐震補強すると考えた場合、現状では 200 ～350 万円の耐震補強費用がかかる。それに対し目標評点最適補 強費用を見ると、静岡では供用年数 7〜8 年頃以降から現状の耐震補 強費用が目標評点最適補強費用を大きく上回っているため、充分な 費用対効果を得られる結果となった。東京や大阪で供用年数 10 年程 度において、費用対効果を得るためには補強費用は 100 万円程度、 20 年では 200 万円以下という結果になった。同様に評点 0.5 を評点 1.0 に寸ることを考えた場合にはそれぞれ 50 万程度と 100 万程度と なった。

ここで、耐震費用については 4.4 で考察したとおりばらつきが大 きいので、前述した耐震補強の事例 50 例 ${ }^{11)}$ を元に個別事例に基づ いて一考する。耐震補強費用の累積度数分布を図 16 に示した。横軸 は補強費用から既往式の $1 / 2$ の額を引いてゼロが概数費用の最適值 となるようにしてある。この図からわかるように、費用対効果を満 足している、つまり費用が見かけ上マイナスになっているものは費 用の安い度数分布の下側の 2 件 $(4 \%)$ のみであった。次いで、費用 対効果が得られやすい補強について分析をするため、補強種類につ いて調べたところ、費用の安い下側 6 件には基礎補強が含まれてい なかった。ここで、診断評点と補強後評点の関係を図 17 に示し、補 強費用の安い下側 5 件について塗りつぶして表記した。費用対効果 の得やすさと診断評点には傾向が見られなかった。

このように地域や補強前の評点を問わず 1.0 の耐震補強を促進する ためには、補強が現在の半額程度の費用で済むようになること、さ らに現在の補強方法では費用対効果を満足しているものが $4 \%$ 程度

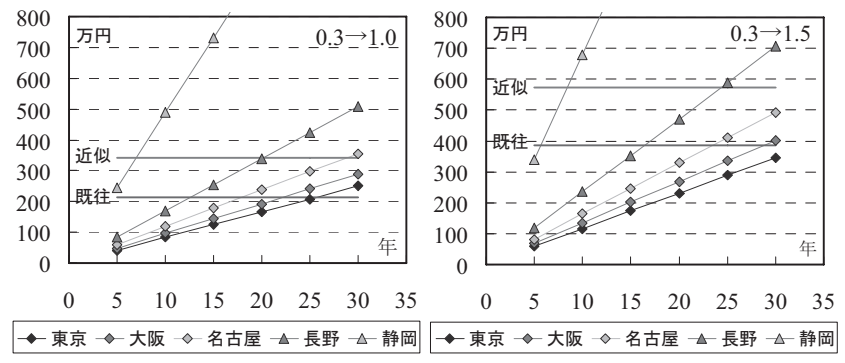

図 14 目標評点最適補強費用 (補強前評点 0.3 )

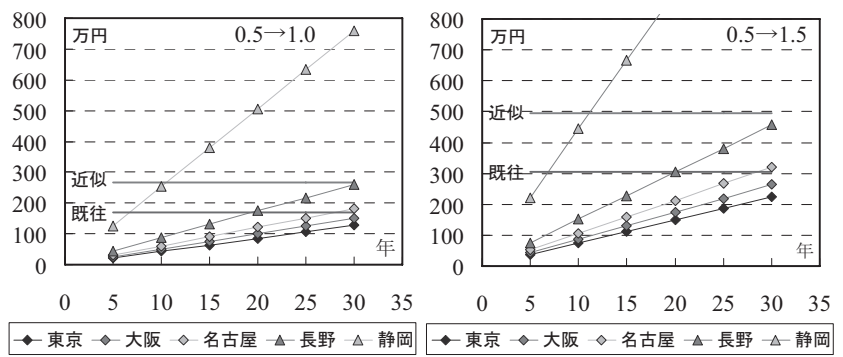

図 15 目標評点最適補強費用 (補強前評点 0.5 )
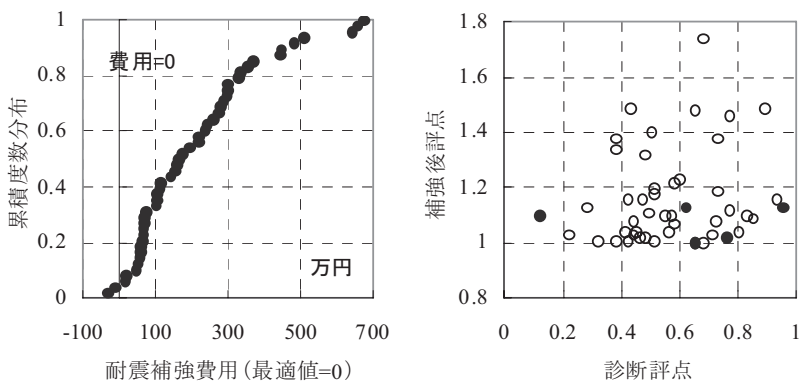

図 16 耐震補強費用の累積度数分布 図 17 診断評点と補強後評点

で、それらには基礎補強が含まれないこと、さらに費用対効果と診 断評点には相関関係が見られないこと、などが明らかとなった。

\section{8. まとめ}

以上、地震危険度の高い木造住宅の費用対効果を論じることを目 的に建物のモデル化手法を整理し、損傷費用や建て替え率などを明 らかにした。

而震補強により軽減される地震リスクに対する損失額の期待值は 地域によって大きく差が見られ、地震発生率が低い地域では、軽減 される地震リスクに対寸る損失額の期待值が而震補強費用を下回っ てしまい、現在の耐震補強費用では費用対効果が得られないという 結果となった。一方、地震発生率が高い地域として選択した静岡で は、現状の耐震補強費用で、 5 年使用寸るのであれば評点 0.7 の補強、 10 年以上使用寸るのであれば評点 1.5 までの補強が最適であるとの 結論を得た。

また、東京、大阪を含む地域において、費用対効果を得る耐震補 強費用を算出した結果、現在の耐震補強費用の半額程度という結論 が得られた。加えて、費用対効果が得られやすい構法を調べたとこ ろ、その中には基礎の補強が含まれてはいなかった。さらに、診断 評点や補強後評点によって費用対効果の得られやすさの傾向は見ら れなかった。なお、以上の算出の前提として、現在入手可能な最新 の知見、補強構法、費用、ハザードマップなどに基づき、さらに既 
存建物の面積や資産価值を新築建物と同じとしているなど、いくつ の仮定下のものであることを断りおくとともに、評点と補強構法、 補強費用の関係や地震発生確率をポアソンモデルとしたことなどは 今後十分な分析が必要と考えている。

はじめにでも述べたとおり、人命はお金に換算できない。つまり、 大地震時に倒壞し人命を損なうことのないよう備えが必要なことは 論を待たない。しかし、経済的な効果がないものに対して投資がな されにくいことも事実である。今後、安価な耐震補強技術の開発が 促進され、経済的な効果も期待できるような環境が整うことを期待 する。

謝辞＼cjkstart本研究は大都市大震災軽減化特別プロジェクト II．振動台活 用による耐震性向上研究のうち、木造建物実験（分担：東京大学）、 IV．地震防災統合化研究のうち事前対策、耐震診断・補強方法の検 討及び開発（分担：独立行政法人建築研究所）の継続研究の一環と して実施し、研究プロジェクトチーム (座長 坂本功慶応大学教授、 幹事 腰原幹雄東京大学生産技術研究所准教授）の方々に貴重な助 言をいただいた。また、耐震補強に関するデー夕は財団法人日本建 築防災協会からご提供いただいた。議論に参加いただいた各位、ご 協力いただいた各位にこの場を借りて感謝します。

\section{参考文献}

1) Takahashi, Y., Der Kiureghian, A. and Ang, A.H-S. (2002)."Decision methodology in seismic risk management of a single building based on minimum expected life-cycle cost", UCB/SEMM Report-2002/02, Department of Civil \& Environmental Engineering, University of California,Berkeley, CA.

2) 高橋雄司, 正木信男, 穴原一範, 五十田博 : 地震危険度の高い地域の建物 を対象とした地震リスク・マネジメント, 日本建築学会構造系論文集, No.591, pp.25-33, 2005.5

3) 井戸田秀樹，嶺岡慎悟，梅村恒，森保宏：在来軸組木造住宅における一般 耐震診断の評点と損傷度の関係 耐震改修促進のための意思決定支援ツー ルに関する研究（その 1 ），日本建築学会構造系論文集，No.612, pp.125-132, 2007.2

4) 飯塚裕暁, 境有紀：実際の建物被害と対応する地震動強さ指標を用いた既 存不適格木造建物の耐震補強における費用対効果の検討, 第 12 回日本地震 工学シンポジウム, CD-ROM, 2006.11

5) 林康裕, 宮腰淳一, 田村和夫, 川瀬博 : 1995 年兵庫県南部地震の低層建物 被害率に基づく最大地動速度の推定, 日本建築学会構造系論文集, No.494, pp.59-66, 1997.4

6) 岡田成幸, 高井伸雄, 木造建築物の損傷度関数の提案と地震防荻への適用 -地震動入力を確定的に扱う場合-, 日本建築学会構造系論文集, No.582, pp.31-38, 2004.8
7) 武村雅之, 池浦友則(1987)：震源の不均等すべりを考慮した半経験的地震 動評価，地震，第 2 輯，第 40 巻，第 1 号, pp.77-78

8) Irikura, K., Prediction of strong acceleration motions using empirical Green's function, Proc. 7th Japan Earthq. Eng. Symp., 151-156, 1986

9) 日本建築学会：建築物荷重指針・同解説 2004, 2004.9

10) 狩谷のぞみ，村尾修，熊谷良雄，糸井川栄一：実デー夕に基づく耐震補 強費用の実態と而震性能向上効果, 地域安全学会論文集, 地域安全学会, No. 7, 263-272,2005.11

11) 財団法人 日本建築防災協会：木造住宅の耐震診断の事例, 2007.3

12) 日本建築防災協会：木造住宅の耐震診断と補強方法, 2004.7

13) the CUREe Caltech Woodframe Project News letter No.1 1998 Nov.

14) Bryan Folz、Andre Filiatrault, A COMPUTER PROGRAM FOR CYCLIC ANALYSIS OF WOOD SHEAR WALLS University of California 2000.10

15) 津田千尋, 服部大介, 佐藤友彦, 五十田博, 宮澤健二：実在木造住宅移築 加振実験, 日本建築学会技術報告集, No.23, pp.149, 2006.6

16) 佐藤友彦, 五十田博, 槌本敬大, 河合直人, 清水秀丸：既存木造住宅と補 強した住宅の動的耐震診断とその精度検証, 日本建築学会構造系論文集, No.618, pp.159-166, 2007.8

17) 篠澤朋宏, 五十田博, 槌本敬大, 中川学, 和田幸子, 篠原昌寿 : 積雪地域 に建つ 2 階建て木造住宅の静的引き倒し実験, 日本建築学会大会学術講演 梗概集，構造III, pp.101-102, 2008.9

18) 五十田博, 平野茂, 三宅辰哉, 古屋治, 箕輪親宏 : 建築基準法の最低壁量 を満足する新築木造住宅の倒壊実験, 日本建築学会構造系論文集, No.618, pp.167-173, 2007.8

19) 野田実, 五十田博, 橋本敏男, 川上修, 高橋仁, 上山耕平：実大木造住宅 の振動台実験手法に関する研究 その 15 等級 2 標準試験体の実験結果, 日 本建築学会大会学術講演梗概集, C-1 分冊, pp.413-414, 2006.9

20) 河合直人, 岡部実, 渡辺一正, 在来軸組構法耐力壁の耐震性能 その 2 仮 動的試験, 日本建築学会大会学術講演梗概集, C-1 分冊, pp.135-136, 1998.9

21) 財団法人 建設物価調査会：建築着工統計データファイル平成 18 年度版 22) 財団法人 日本建築防災協会、社団法人 日本建築士連合会: 木造住宅の耐 震精密診断と補強方法, 1985

23）建設省建築研究所、日本建築センター：設計用入力地震動作成手法技術 指針(案)、平成 4 年 3 月

24) 今津雅紀, 福武毅芳：砂礫材料の動的変形特性, 第 21 回土質工学研究発 表会, pp.509-512, 1986

25）福武毅芳：土の多方向繰り返しせん断特性を考慮した地盤・構造物系の 三次元液状化解析に関寸る研究, 名古屋工業大学博士論文, 1997

26) 独立行政法人防災科学技術研究所強震観測網 K-NET 入手先 (http://www.k-net.bosai.go.jp/k-net/)

27) 日本建築学会：2004 年 10 月 23 日新潟県中越地震災害調査報告、2006.8

28) 岡田成幸, 高井伸雄 : 地震被害調查のための建物分類と破壞パターン. 日本建築学会構造系論文報告集, No.524, pp.65-72, 1999.10

29) 日本建築防荻協会：震災建築物の被荻度区分判定基準および復旧技術指 針, 2001, 9

2008年 3 月 10 日原稿受理，2008年11月21日採用決定） 